WITOLD FILIPCZAK

UNIWERSYTET ŁÓDZKI

\title{
Stanisław August i Elżbieta Sapieżyna. Spór wokół losów sejmu 1782 roku
}

Dzieje relacji między Stanisławem Augustem Poniatowskim i Elżbieta $z$ Branickich Sapieżyna to problem skomplikowany, a zarazem intrygujaccy. Łaczyły się w nich watki osobiste (wojewodzicowa mścisławska była przez pewien czas królewska kochanką) i polityczne ${ }^{1}$. Czuję się jednak zwolniony $z$ dokładniejszego omawiania problemu, gdyż pisałem już na ten temat zajmując się rola matki Kazimierza Nestora Sapiehy w czasie kampanii sejmowej w 1778 r. ${ }^{2}$ Ograniczę się tu więc do podania najbardziej tylko istotnych informacji. Romans E. Sapieżyny ze Stanisławem Poniatowskim zaczą się w roku 1764 - prawdopodobnie jeszcze w czasie bezkrólewia po śmierci Augusta III Wettyna (choć już wcześniej wojewodzicowa mścisławska pożyczyła stolnikowi litewskiemu znaczną sumę) $)^{3}$ W ciagu pierwszych kilku lat po elekcji nowego monarchy E. Sapieżyna odgrywała znaczaca rolę polityczną w jego otoczeniu. Stanisław August wykorzystywał inteligencję i wymowę księżnej

1 M. C z e p p e, Sapieżyna z Branickich Elżbieta, [w:] Polski słownik biograficzny [dalej: PSB], t. XXXV, Wrocław 1994, s. 163; K. Z i e n k o w s k a, Stanisław August Poniatowski, Wrocław-Warszawa-Kraków 1998, s. 248-249.

2 W. Fili p c zak, Elżbieta Sapieżyna na tle politycznej roli kobiet $w$ czasie kampanii sejmowej z 1778 roku, [w:] Niebem i sercem okryta. Studia historyczne dedykowane dr Jolancie Malinowskiej, red. M. Malinowski, Torun 2002, s. 303326.

${ }^{3}$ M. C z e p p e, op. cit., s. 163. Por. M. M a t u s z e wi c z, Diariusz życia mego, oprac. B. Królikowski, komentarz Z. Zielińska, t. II (1758-1764), Warszawa 1986, s. 619. Należy jednak zauważyć, że uwaga M. Matuszewicza dotycząca początków królewskiego romansu odnosi się, przede wszystkim, do wojewodziny połockiej Magdaleny Sapieżyny. 
wojewodzicowej w różnych delikatnych misjach, np. w kontaktach $z$ ambasadą rosyjską ${ }^{4}$.

Stosunki między królem a wojewodzicową mścisławską uległy zdecydowanemu pogorszeniu, kiedy w dobie pierwszego sejmu rozbiorowego do opozycji przeszedł brat E. Sapieżyny, Franciszek Ksawery Branicki ${ }^{5}$. Księżna wojewodzicowa wsparła, wraz z K.N. Sapieha, generałem artylerii litewskiej (otrzymał ten urząd w 1773 r.), linię polityczna hetmana wielkiego koronnego. Nie mogło to pozostać bez wpływu na relacje między nią a Stanisławem Augustem. W 1776 r. K.N. Sapieha wybrany został posłem na burzliwym, „psutym" przez regalistów sejmiku przedsejmowym w Słonimiu. Ostatecznie jednak nie został dopuszczony do uczestnictwa w obradach ${ }^{6}$. W roku 1778 księżna wojewodzicowa, mając akceptację ambasadora rosyjskiego Ottona $M$. von Stackelberga, patronowała elekcji syna na posła brzesko-litewskiego (wpływy na tym sejmiku były dla niej szczególnie istotne ze względu na bliskość sapieżyńskiego Kodnia). Na sejmie jesienią tegoż roku K.N. Sapieha został wybrany w skład Rady Nieustającej, gdzie jednak, w wyniku decyzji króla, zasiadł w Departamencie Skarbowym, a nie Wojskowym? ${ }^{7}$. Następny sejm, w roku 1780, miał być w intencjach E. Sapieżyny, przełomowy w karierze syna. General artylerii litewskiej, jako konsyliarz Rady Nieustającej, nie mógł starać się o mandat poselski 8 . Ubiegał się jednak, korzystając $z$ pomocy matki, o prestiżową funkcję marszałka Rady Nieustającej (w latach 1778-1780 był nim Ignacy Potocki)9. Podobno kandydatura K.N. Sapiehy miała początkowo

${ }^{4}$ M. C z e p p e, op. cit., s. 163-164; K. Z i e n kow s k a, op. cit., s. 144, 248.

5 J. M ichals ki, Początki opozycyjnej działalności Franciszka Ksawerego Branickiego, „Kwartalnik Historyczny” 2006, R. CXIII, nr 2, s. 78-129; ide m, $O$ zmiane rosyjskiego ambasadora $w$ Warszawie (zabiegi magnackiej opozycji w latach 1775-1776), „Kwartalnik Historyczny” 2002, R. CIX, nr 3, s. 150-151.

6 W. Fili p c z a k, Sejm 1778 roku, Warszawa 2000, s. 100. Por. też Ł. Ka d z i e l a, Sapieha Kazimierz Nestor, [w:] PSB, t. XXXV, Warszawa 1994, s. 53.

7 W. Fili p c zak, Elżbieta Sapieżyna..., s. 314-323; id e m, Wybory Rady Nieustajacej na sejmie 1778 roku, "Acta Universitatis Lodziensis”, Folia historica 64, 1999, s. 120, 127, 132.

8 Volumina legum [dalej: Vol. leg.], t. VIII, wyd. J. Ohryzko, Petersburg 1860, s. 72 (Ustanowienie Rady Nieustajacej, artykuł II); W. Fili p czak, Ekonomie litewskie $w$ polityce sejmikowej Stanisława Augusta po upadku Antoniego Tyzenhauza (1780-1783), „Przegląd Nauk Historycznych” 2006, R. V, nr 1 (9), s. 264.

9 Król do Elżbiety Sapieżyny, 22 i 29 V 1780 oraz E. Sapieżyna do króla, 24 V 1780, Biblioteka Czartoryskich w Krakowie [dalej: BCz], rkps 708, s. 780-781, 796-797, 803; M. C z e p p e, op. cit., s. 165. Por. też Z. Zi e liń s ka, Potocki Ro- 
akceptację (przynajmniej oficjalnie) Stanisława Augusta i O. Stackelberga ${ }^{10}$. Ostatecznie jednak sejm wybrał na tę funkcję, większościa głosów (w diariuszach nie zostały podane dokładne wyniki elekcji), królewskiego bratanka Stanisława Poniatowskiego ${ }^{11}$. Ciekawą relację na ten temat można znaleźć w liście F.K. Branickiego do Seweryna Rzewuskiego. Hetman wielki koronny, jak sam twierdził, początkowo niechętnie odnosił się do aspiracji siostrzeńca, które jednak poparł wobec jego nalegań. F.K. Branicki tak pisał do hetmana polnego koronnego: „Książe Sapieha, generał artylerii, z powodu samego J[ego] K[rólewskiej] M[oś]ci i Posła determinowany był za marszałka Rady Nieustajacej, noc ostatnia przed elekcja przerobiła to wszystko i księcia Stanisława Poniatowskiego obrano"12. Sprawa ta, jak się wydaje, miała istotny wpływ na dalsze relacje między królem a rodziną E. Sapieżyny. Księżna wojewodzicowa gotowa była poprzeć nawet rezygnację syna $z$ konsyliarstwa Rady, do czego ostatecznie nie doszło ${ }^{13}$.

W korespondencji ze Stanisławem Augustem Elżbieta Sapieżyna, nieodmiennie deklarująca swe wobec niego przywiązanie, próbowała występować $\mathrm{w}$ roli pośrednika między królem a swoim bratem ${ }^{14}$. Również monarcha usiłował, jednak bezskutecznie, poprzez księżnę wojewodzicową przeciwdziałać planom małżeństwa F.K. Branickiego $z$ Aleksandra Engelhardt ${ }^{15}$, naturalna córka Katarzyny II, a rzekoma siostrzenicą Grigorija Potiomkina ${ }^{16}$. Generalnie rzecz bio-

man Ig nacy, [w:] PSB, t. XXVIII, Wrocław 1984-1985, s. 3; Z. J a n e c zek, Ignacy Potocki. Marszałek Wielki Litewski (1750-1809), Katowice 1992, s. 41.

10 Franciszek Ksawery Branicki do Seweryna Rzewuskiego, 4 XI 1780, Archiwum Państwowe w Krakowie [dalej: APK], Archiwum Podhoreckie [dalej: Podh.], sygn. II 2/5, nr 44.

11 Dyaryusz Seymu wolnego ordynaryinego... 1780..., wyd. S. Badeni, Warszawa b.d., s. 28; Diariusz Sejmu jw. Małachowskiego [zaczętego] 2 X 1780 spisany przez Konarskiego, Archiwum Główne Akt Dawnych w Warszawie [dalej: AGAD], Zbiór Popielów [dalej: ZP] nr 125, k. 331-331v. Por. L. Ką d zi ela, op. cit., s. 53.

12 F.K. Branicki do S. Rzewuskiego, 4 XI 1780, APK, Podh. II 2/5, nr 44.

13 M. C z e p p e, op. cit., s. 165.

14 W. Fili p c z a k, Elżbieta Sapieżyna..., s. 317-325. Por. K. Z i e n k ow s k a, op. cit., s. 248-249.

15 M. C z e p p e, op. cit., s. 165; T. O s trow s ki, Poufne wieści z oświeconej Warszawy, oprac. R. Kaleta, Wrocław 1972, s. 228-229 (przyp. 76).

16 E. Rostworowski, Sprawa aukcji wojska na tle sytuacji politycznej przed Sejmem Czteroletnim, Warszawa 1957, s. 119; E. Zi eli ń s k a, Otto Magnus Stackelberg wobec projektu skonfederowania sejmu 1782 roku. Przyczynek 
rąc, w pierwszych miesiącach 1782 r., kiedy doszło do głośnej sprawy biskupa krakowskiego Kajetana Sołtyka, relacje między monarchą a jego była kochanka sprawiały wrażenie przynajmniej poprawnych. Przykładem może być stosunek Stanisława Augusta do, powszechnie znanych już w styczniu 1782 r., zabiegów K.N. Sapiehy o rękę Anny z Cetnerów Sanguszkowej, wdowy po marszałku wielkim litewskim Józefie Sanguszce ${ }^{17}$. W dniu 17 lutego 1782 r. E. Sapieżyna informowała króla, że trzy dni wcześniej (14 lutego) jej syn otrzymał pozytywna deklarację młodej wdowy na swoje oświadczyny. Stanisław August w odpowiedzi złożył serdeczne powinszowania, na ręce wojewodzicowej mścisławskiej, generałowi artylerii litewskiej, A. Sanguszkowej i jej ojcu Ignacemu Cetnerowi, wojewodzie bełskiemu ${ }^{18}$. W końcu tegoż miesiąca E. Sapieżyna prosiła monarchę o pomoc w uzyskaniu papieskiej dyspensy, koniecznej do zawarcia małźeństwa19. Starania te zakończyły się sukcesem. Pozwoliło to, w czerwcu 1782 r., zawrzeć ślub, co przyniosło generałowi artylerii litewskiej ogromne korzyści majątkowe ${ }^{20}$. W marcu 1782 r. E. Sapieżyna apelowała do króla o protekcję dla syna, gdyż zagrożone były dobra K.N. Sapiehy znajdujace się w zaborze pruskim. W poczatkach kwietnia księżna wojewodzicowa dziękowała Stanisławowi Augustowi za, związana $z$ ta sprawa, rezolucję Rady Nieustającej, w odpowiedzi na notę H. Ludwiga Buchholtza, posła pruskiego w Warszawie ${ }^{21}$. Czyniąc te gesty pod adresem Sapiehów monarcha oczekiwał rewanżu, czemu dał wyraz już w dzień po uchwaleniu przez Radę Nieustająca (22 marca 1782 r.) rezolucji $\mathrm{w}$ sprawie potajemnych małżeństw ${ }^{22}$. Miała ona związek ze spora-

do praktyki polityki rosyjskiej $w$ Rzeczypospolitej przed Sejmem Wielkim, „Kwartalnik Historyczny" 1999, R. CVI, nr 4, s. 78 (przyp. 21).

$17 \mathrm{O}$ sprawie tej głośno było już w gazetkach pisanych: $Z$ Warszawy, 10 stycznia 1782 i Suplement wiadomości de 17 januarii 1782, [w:] T. O s trow s ki, op. cit., s. 44, 49; Ł. Ką d zi e la, op. cit., s. 53.

18 Elżbieta Sapieżyna do króla, 17 II 1782, BCz, rkps 931, s. 75. Z notatki pod listem (s. 77) wynika, że królewska odpowiedź, z powinszowaniami, nosiła date 28 II 1782. Por. B. Z a le s ki, Korespondencja krajowa Stanisława Augusta od 1784 do 1792, Poznań 1872, s. 13-14.

19 Elżbieta Sapieżyna do króla, 26 II 1782, BCz, rkps 930, s. 95.

20 Ł. K ą d zi el a, op. cit., s. 53.

21 Elżbieta Sapieżyna do króla, 13 III i 3 IV 1782, BCz, rkps 931, s. 79-81, 83-84.

22 Protokół Rady Nieustającej z 22 III 1782, AGAD, tzw. Metryka Litewska [dalej: ML], sygn. VII/40, k. 84; król do Elżbiety Sapieżyny, 23 III 1782, BCz, rkps 930, s. 97. 
mi Sapiehów z rodziną Moszczeńskich, które dotyczyły spadku po łowczynie litewskiej Katarzynie Sapieżynie (chodziło o pretensje sukcesorów $z$ jej sekretnego małżeństwa) ${ }^{23}$. Król oczekiwał od E. Sapieżyny umorzenia kondemnaty uzyskanej na szambelanie (zapewne Adamie) Moszczeńskim²4. W maju 1782 r. księżna przyjechała do posiadanej przez F.K. Branickiego Białej Cerkwi, jak pisała, „w kraj [...] bardzo jeszcze pusty i wiele dzikości w sobie mający", gdzie zamierzała poznać swoją bratową ${ }^{25}$.

Te dość sielankowo przedstawiające się relacje między królem a E. Sapieżyną miały zakłócić wydarzenia, które sprowokowały najpoważniejszy kryzys polityczny w czasach wolnych sejmów okresu Rady Nieustajacej. Sprawa ubezwłasnowolnienia przez kapitułę krakowska biskupa K. Sołtyka, zdradzajacego objawy choroby psychicznej, była już omawiana w literaturze przedmiotu. Najobszerniej pisał na ten temat Kazimierz Rudnicki26. Ostatnio najważniejsze wydarzenia $z$ tym związane przedstawiła też Maria Czeppe ${ }^{27}$. Parlamentarna dyskusje nad sprawa krakowska na sejmie $z$ roku 1782 analizował Andrzej Stroynowski28, międzynarodowymi aspektami ówczesnej sytuacji zajmowała się zaś Ewa Zielińska ${ }^{29}$. Zwalnia to mnie ze szczegółowego prezentowania zagadnienia. Ograniczę się więc do spraw najistotniejszych dla omawianego tematu.

W końcu stycznia i w lutym 1782 r. biskup K. Sołtyk zachowywał się w sposób, który wskazywał na brak równowagi psychicznej (podejmowanie czynności liturgicznych bez właściwego przygotowania, odprawianie nocnych nabożeństw). Obawy budziła również nadzwyczajna hojność biskupa krakowskiego oraz jego plany

23 Opisanie sprawy z Ichmość Panami Moszczeńskimi, BCz, rkps 931, s. 87; M. C z e p p e, op. cit., s. 165.

${ }^{24}$ Król do E. Sapieżyny, 23 III 1782, BCz, rkps 930, s. 97.

25 Elżbieta Sapieżyna do króla, 3 V 1782, BCz, rkps 930, s. 99-100.

26 K. Rudnicki, Biskup Kajetan Soltyk 1715-1788, Kraków-Warszawa 1906, s. 207-227.

27 M. C z e p p e, Sołtyk Kajetan Ignacy, [w:] PSB, t. XL, Warszawa-Kraków 2001 , s. 400-402.

${ }_{28}$ A. S t r o y n o w s ki, Opozycja sejmowa $w$ dobie rzadów Rady Nieustającej. Studium z dziejów kultury politycznej, Łódź 2005, s. 158-164.

29 W 2005 r. Ewa Zielińska obroniła w Instytucie Historii PAN w Warszawie pracę doktorska pt. Rzeczpospolita wobec zbliżenia rosyjsko-austriackiego $w$ poczatkach lat osiemdziesiatych XVIII wieku. Sprawa barona Karla Juliusa i biskupa Kajetana Soltyka: http://nauka-polska/dthml/raporty/praceBadawcze [dostęp: kwiecień 2010]. 
wyjazdu do Galicji30. Doszło do jawnego konfliktu między ordynariuszem a kapituła, gdyż biskup publicznie łajał kanoników oraz zmusił ich do przybrania koadiutorów. Wobec oporu ze strony kapituły, K. Sołtyk pozbawił urzędu archidiakona krakowskiego ks. Józefa Olechowskiego, a kanclerstwa katedralnego - ks. Józefa Gorzeńskiego. Rzucił również interdykt na nieposłusznych kanoników ${ }^{31}$. Kapituła $z$ kolei uznała, że biskup postradał zmysły i wezwała do objęcia diecezji jego koadiutora, a zarazem królewskiego brata, biskupa płockiego Michała Poniatowskiego. W dniu 23 lutego 1782 r. kapituła ubezwłasnowolniła biskupa, który umieszczony został w seminarium duchownym ${ }^{32}$. Skorzystano przy tym $z$ pomocy wojskowej ze strony garnizonu krakowskiego (którym dowodził wówczas Józef Wodzicki). Zgodnie $z$ ordynansem Departamentu Wojskowego Rady Nieustającej miał on współdziałać $z$ kapituła krakowską ${ }^{33}$. Działania te wywołały oburzenie obecnej w Krakowie szlachty (ogłosiła ona 1 marca manifest) oraz mieszczan, którzy występowali w obronie biskupa ${ }^{34}$.

Wydarzenia krakowskie bacznie śledziła antykrólewska opozycja. Jej przedstawiciele próbowali lansować pogląd, że biskup K. Sołtyk jest zdrowy na umyśle, a przynajmniej był taki $\mathrm{w}$ momencie zatrzymania. Starosta łukowski Sebastian Dłuski przesyłał Ignacemu Potockiemu szczegółowe informacje o sytuacji w Krakowie i o zachowaniu K. Sołtyka. Sondowano, czy możliwe jest pokierowanie działaniami biskupa krakowskiego, zgodnie $z$ wytycznymi liderów Nowej Familii ${ }^{35}$. Scenariusze takich działań można znaleźć w papierach przywódcy ugrupowania, marszałka wielkiego koronnego Stanisława Lubomirskiego. Jednym $z$ celów stronnictwa puławskiego było doprowadzenie do wyjazdu biskupa K. Sołtyka do s. 400

30 K. Rudnicki, op. cit., s. 205-207; M. Czeppe, Soltyk Kajetan...,

${ }^{31}$ K. Rud n i cki, op. cit., s. 207-212; M. C z e p p e, Soltyk Kajetan..., s. 400401.

32 Kopia raportu Józefa Wodzickiego z 23 II 1782, AGAD, ZP nr 28, cz. IV, k. 65; K. Rud n i cki, op. cit., s. 210-215, M. C z e p p e, Soltyk Kajetan..., s. 401.

33 Wypis $z$ protokołu sekretnego Departamentu Wojskowego. Sesja z 15 II 1782, AGAD, ZP nr 28, cz. IV, k. 60-60v.

34 Manifest $z 1$ III 1782, AGAD, Archiwum Publiczne Potockich [dalej: APP] nr 313, t. XI, s. 149-152. Z manifestem wystapił, już 23 II 1782, wojewoda bracławski Maciej Lanckoroński (s. 147-148). Por. też S. C y narski, Dzieje rodu Lanckorońskich z Brzezia od XIV do XVIII wieku, Warszawa-Kraków 1996, s. 206.

35 Korespondencja Sebastiana Dłuskiego do Ignacego Potockiego $z$ okresu 27 II - 12 IV 1782, AGAD, APP nr 279a/74, s. 55-88. 
Galicji (co wiazało się $z$ nadziejami na interwencję cesarza Józefa II) ${ }^{36}$. Zwiazani $z$ Nowa Familia konsyliarze (m.in. S. Lubomirski i I. Potocki) na sesjach Rady Nieustającej z 26 lutego i 1 marca 1782 r. zajęli się sprawę ubezwłasnowolnienia biskupa, domagając się jego uwolnienia i krytykując kapitułę. W głosowaniach opozycja poniosła porażkę ${ }^{37}$. Uzyskano jedynie tyle, że Rada zażądała wyjaśnień od kapituły. Szczególna aktywność w sprawie krakowskiej przejawiał Seweryn Rzewuski. Hetman polny koronny był obecny w Krakowie, gdzie aktywnie zaangażował się w akcję na rzecz uwolnienia biskupa krakowskiego. Próbował m.in. zachęcić do działania S. Dłuskiego, który coraz pesymistyczniej oceniał stan zdrowia K. Sołty$\mathrm{ka}^{38}$. S. Rzewuski skierował też dwa listy, do monarchy i do Rady Nieustajacej. Duży rozgłos zyskało to drugie pismo, z 28 marca 1782 r., ze względu na ostry atak na magistraturęe39. Po wyjeździe $z$ Krakowa, hetman S. Rzewuski był informowany o sytuacji przez Jacka Bzowskiego ${ }^{40}$. Wcześniej (w końcu lutego) w Krakowie rozpoczął działalność, jako przedstawiciel jurysdykcji metropolity gnieźnieńskiego Antoniego Ostrowskiego, biskup chełmski Maciej Garnysz. Miał on rozstrzygnać konflikt oraz rozpatrzyć zażalenia na kapitułę krakowska, która oskarżano o niewłaściwe traktowanie ordynariusza ${ }^{41}$. Wbrew żądaniom opozycji, nałożone, wyrokiem $z$ początku kwietnia, kary na kapitułe (za zatrzymanie biskupa i senatora $\mathrm{w}$ nieodpowiednim miejscu) miały symboliczny charakter ${ }^{42}$. W dniu 5 marca 1782 r. król wyznaczył komisję do zbadania stanu zdrowia K. Sołtyka, $z$ kanclerzem i biskupem poznańskim Antonim Onufrym Okęckim na czele. W noszacym datę 3 kwietnia 1782 r. orzeczeniu uznała ona, iż biskup, ze względu na stan umysłu, nie

36 „Zbiór myśli”, AGAD, APP nr 313, t. XI, s. 243-246.

37 Protokół Rady Nieustającej z 26 II i 1 III 1782, AGAD, ML VII/40, k. 6667, 68v-70; Zdanie Stanisława Lubomirskiego... na sesji Rady Nieustającej 1 III 1782, Zdanie Ignacego Potockiego na sesji Rady z 1 III 1782, AGAD, APP nr 313, t. XI, s. 143-145, 153-155; K. R u d n i c ki, op. cit., s. 218-220.

38 Sebastian Dłuski do Ignacego Potockiego, 12 IV 1782, AGAD, APP nr 279a/74, s. 85-88.

39 K. Rudnicki, op. cit., s. 224-225; Z. Zi elińs ka, Rzewuski Seweryn, [w:] PSB, t. XXXIV, Wrocław 1992, s. 142.

40 Jacek (Hiacynt) Bzowski do Seweryna Rzewuskiego, 20 IV, 7 i 17 V 1782, APK, Podh. II 2/11, nr 84-86.

41 M. C z e p pe, Sołtyk Kajetan..., s. 401. Por. notatka, bez tytułu i daty, AGAD, APP nr 313, t. XI, s. 258-259.

42 Sebastian Dłuski do króla, 28 III 1782, AGAD, APP nr 279a/74, s. 72-80;

K. Rud n i cki, op. cit., s. 218-223. 
może zarządzać ani diecezją, ani swoim majątkiem ${ }^{43}$. W dniu 9 kwietnia 1782 r., król wydał reskrypt, w którym ustanawiał kuratorów. Zostali nimi trzej członkowie rodziny Sołtyków, $z$ wojewoda sandomierskim Maciejem na czele (wojewoda krakowski Piotr Małachowski nie przyją nominacji); w maju biskup krakowski został przewieziony do Kielc ${ }^{44}$. W gronie kuratorów biskupa nie znalazł sie jego synowiec, sekretarz wielki koronny ks. Maciej Kajetan Sołtyk. Mogło to mieć zwiazek z jego opozycyjnymi poczynaniami politycznymi. Był on w dobrych relacjach $z$ hetmanem F.K. Branickim (uczestniczył w jego ślubie) i K.N. Sapiehą. Jadacc z Petersburga do Krakowa, w Warszawie przekazał O. Stackelbergowi list od G. Potiomkina ${ }^{45}$.

Generalnie rzecz biorąc, ośrodek białocerkiewski zaangażował się w sprawę krakowską w mniejszym stopniu niż Nowa Familia i S. Rzewuski. Nie można więc wykluczyć, że - wzmiankowane wcześniej - przyjazne gesty Stanisława Augusta wobec E. Sapieżyny i jej syna obliczone były na ich zneutralizowanie wobec nadciągającego nieuchronnie konfliktu na forum parlamentarnym. Należało się bowiem spodziewać, że magnacka opozycja wykorzysta "aferę" sołtykowską do ataku na Departament Wojskowy i cała Radę Nieustająca jako instytucje współodpowiedzialne (w ocenie opozycji) za naruszenie kardynalnego prawa neminem captivabimus. Dość obfita była publicystyka polityczna, w której prezentowano dworskie i opozycyjne wersje wydarzeń zwiąanych $z$ osoba biskupa K. Sołtyka ${ }^{46}$. W tej sytuacji dwór wyjątkowo starannie przygotowywał się do kampanii sejmikowej. Stanisław August w korespondencji $z$ przywódcami regalistów w poszczególnych wojewódz-

43 Zdanie... delegowanych komisarzów... z 3 IV 1782, AGAD, APP nr 313, t. XI, s. 230-233; K. R u d n i c ki, op. cit., s. 223-224.

44 Jacek Małachowski do Piotra Małachowskiego, 1 V 1782. Biblioteka Zakładu Narodowego im. Ossolińskich we Wrocławiu, rkps 11860, s. 35; M. C z e p p e, Sołtyk Kajetan..., s. 401; R. Cywińs ki, Sołtyk Maciej, [w:] PSB, t. XL, Warszawa-Kraków 2000, s. 411.

45 Maciej Kajetan Sołtyk do [Kazimierza Nestora Sapiehy], 9 IV 1782 i M.K. Sołtyk do [Franciszka Ksawerego Branickiego] z 9 IV 1782, BCz, rkps 931, s. 95-98; M. Cze p pe, J. Śmiałow ki, Soltyk Maciej Kajetan, [w:] PSB, t. XL, Warszawa-Kraków 2000, s. 405.

46 Szereg tego rodzaju tekstów (m.in.: „List przyjaciela z Krakowa do Warszawy pisany”, „Respons na list przyjaciela z Krakowa do Warszawy pisany”, „Kopia listu do... koadiutora krakowskiego”, apokryficzna „Kopia manifestu przez kapitułę krakowska...”) znajduje się w papierach S. Lubomirskiego: AGAD, APP nr 313, t. XI, s. 187-203, 236-238, 297-298. 
twach podkreślał, że nie można dopuścić do umieszczenia sprawy krakowskiej w instrukcjach poselskich. Zalecał także punkty dotyczace pensji dla deputatów trybunalskich oraz przeznaczenia nadwyżek Skarbu Koronnego na poszukiwania soli i kruszców, które to sprawy znalazły się na sejmie wśród, zgłoszonych w imieniu króla, propozycji od tronu ${ }^{47}$. Szybko okazało się jednak, że dwór nie może liczyć na neutralność stronnictwa białocerkiewskiego. W posejmowej korespondencji E. Sapieżyna pisała, że już na trzy miesiace przed sejmem biskup M. Poniatowski wiedział o jej negatywnym stosunku do poczynań kapituły48. Hetman F.K. Branicki $z$ dużym rozmachem prowadził kampanię na rzecz opozycyjnych kandydatów w czasie sejmików poselskich. We wrześniu roku 1782, niezadowolony $z$ wiadomości, że S. Rzewuski nie zamierza wziaćc udziału w sejmie, podkreślał własne zasługi pisząc $z$ pewna przesadą: „Ja zacząwszy od Kijowa, aż do Łęczycy robiłem posłów i jest ich kilkadziesiąt"49. K.N. Sapieha, po przeprowadzce do Lubartowa, działał w województwie lubelskim. Na tamtejszym sejmiku przedsejmowym realizował dość dwuznaczna taktykę; prowadził układy zarówno $z$ regalistami, jak i reprezentujacym Nową Familia, Stanisławem Kostka Potockim ${ }^{50}$.

Król bacznie obserwował zachowanie F.K. Branickiego, m.in. korzystając $z$ informacji kasztelana kijowskiego Józefa Stempkowskiego. W połowie września tak pisał do E. Sapieżyny: „Dochodza mnie $z$ różnych stron wiadomości, że lubo jp. Hetman - brat WPani często publicznie, kiedy po trzeźwu mówią, wszystko dobrze dla mnie, jednak kiedy sobie podochoci, to przed różnemi osobami kilkakrotnie powiedział, że musi być koniecznie coś zrobiono na sejmie, co by się wcale nie zgadzało $z$ temi dobremi oświadczeniami"51. Wykreślony przez monarchę fragment nie pozostawia wąt-

47 Król do Franciszka Czackiego, 7 VI 1782, BCz, rkps 655, s. 816-817; Dyaryusz Seymu wolnego... 1782..., wyd. P. Kiciński, Warszawa 1782, s. 40-41.

48 Elżbieta Sapieżyna do króla, 26 XI 1782, BCz, rkps 931, s. 111.

49 Franciszek Ksawery Branicki do Seweryna Rzewuskiego, 17 IX 1782, APK, Podh. II 2/5, nr 46. Por. też E. R o s tw o r o w s k i, Sprawa aukcji wojska..., s. 119; W. Fili p c z a k, Stronnictwo regalistyczne..., s. 103.

50 Józef Mierzejewski do Elżbiety Sapieżyny, 21 VIII 1782, AGAD, Archiwum Komierowskich, sygn. 12/12, s. 137-138; król do Andrzeja Mokronowskiego, 5 VIII 1782, BCz, rkps 927, s. 869.

${ }^{51}$ Król do Elżbiety Sapieżyny, 16 IX 1782, BCz, rkps 931, s. 103; B. Z a le s k i, op. cit., s. 14. Por. Józef Stempkowski do króla, 11 IX 1782, BCz, rkps 688, s. $473-474$. 
pliwości, że chodziło o atak na kapitułę krakowską i Departament Wojskowy. Nic więc dziwnego, że w tej sytuacji król nie uwzględnił protekcji wojewodzicowej mścisławskiej przy obsadzie urzędów lubelskich ${ }^{52}$. Trudno powiedzieć, czy Stanisław August miał jeszcze nadzieję w kwestii postawy stronników F.K. Branickiego na sejmie. Monarcha próbował się jednak odwołać do, tak chętnie deklarowanego, przywiązania E. Sapieżyny. Apelował do niej o działania zgodne $\mathrm{z}$ królewskimi interesami. Wskazywał na potrzebe spotkania, pisząc: „Pół godziny rozmowy więcej zrobi jak 10 listów”53. W tym kontekście dość zaskakująco brzmią posejmowe skargi księżnej wojewodzicowej. W końcu listopada pisała ona: „od przyjazdu mego do Warszawy, ani WKMć ze mną o żadnym interesie nie mówił, ani mi żadnego komisu nie wydał przez nikogo"54. W grudniu $1782 \mathrm{r}$. E. Sapieżyna stwierdziła, że także jej brat po przybyciu do stolicy chciał skontaktować się z M. Poniatowskim, który jednak tego unikał. Wojewodzicowa mścisławska powoływała się również na swoje przestrogi, które przesyłała za pośrednictwem pisarza koronnego Adama Cieciszowskiego, szefa Gabinetu Stanisława Augusta55. Kontakty hetmana $z$ biskupem płockim, niezależnie od partyjnych podziałów, zasługuja na uwagę. Warto przypomnieć, że na sejmie $z$ roku 1780 F.K. Branicki, prawdopodobnie $z$ inspiracji królewskiego brata, zaangażował się przeciwko powołaniu nadzwyczajnego sądu do rozpatrzenia zarzutów przeciwko podskarbiemu litewskiemu Antoniemu Tyzenhauzowi56.

Nie jest moim zamiarem zajmować się szczegółowo dziejami sejmu, który obradował od 30 września do 9 listopada 1782 r. Sporo informacji na ten można znaleźć w pracach Henryka Schmitta, K. Rudnickiego i A. Stroynowskiego ${ }^{57}$. Losy tego sejmu to problem bardzo skomplikowany, który wymaga jeszcze szczegółowych ba-

52 W liście z 12 IX 1782 E. Sapieżyna prosiła o stolnikostwo urzędowskie dla podczaszego lubelskiego Stanisława Wybranowskiego, BCz, rkps 931, s. 101.

53 Król do Elżbiety Sapieżyny, 16 IX 1782, ibidem, s. 103.

54 Elżbieta Sapieżyna do króla, 26 XI 1782, ibidem, s. 106.

55 Elżbieta Sapieżyna do króla, 7 XII 1782, ibidem, s. 125-126. Na temat roli A. Cieciszowskiego por. też M. Ry m s z y n a, Gabinet Stanisława Augusta, Warszawa 1962, s. 114-115.

56 S. Ko ści i łk owski, Antoni Tyzenhauz. Podskarbi nadworny litewski, t. II, Londyn 1971, s. 433-434.

57 H. S c h m itt, Dzieje Polski XVIII wieku osnowane przeważnie na niewydanych dotąd źródłach, t. III, Kraków 1867, s. 69-76; K. Rudnicki, op. cit., s. 227-242; A. S t roy now s ki, op. cit., s. 156-169. 
dań. Należy podkreślić, że na wielu sesjach (od 21 października do 2 listopada) toczyła się burzliwa dyskusja nad sprawa sołtykowską58. Opozycji magnackiej udało się zdobyć poparcie większe niż na innych sejmach czasów Rady Nieustajacej. Wyrazem tego były głosowania (dwa jawne i jedno tajne) nad czterema punktami opozycyjnego projektu $O$ rezolucjach Rady, wniesionego przez posła lubelskiego Stanisława Kostkę Potockiego. W jawnych głosowaniach $\mathrm{w}$ izbie poselskiej opozycja dysponowała zwykle poparciem 35-38 osób. W tajnych wotowaniach największa liczba głosów za wnioskiem S.K. Potockiego (jego pierwszym punktem) wyniosła 83 (67 posłów i 16 senatorów na 219 parlamentarzystów) ${ }^{59}$. Osobnym problemem jest postawa marszałka sejmu Kazimierza Krasińskiego, o którym pisano, że nie ma powagi w izbie poselskiej60. Oboźny koronny nie tylko w tej sprawie zawiódł regalistów (pierwotnie kandydatem króla do laski marszałkowskiej był sekretarz koronny Michał Granowski). K. Krasiński w czterech (na osiem) jawnych wotowaniach poparł projekt S.K. Potockiego ${ }^{61}$. Obstrukcyjna taktyka opozycji oraz nieustępliwa postawa regalistów spowodowała paraliż prac sejmu. Wśród malkontentów nie zabrakło też F.K. Branickiego. Hetman wielki koronny wykorzystał sprawę krakowską do pochwały dawnej władzy buław nad wojskiem62. Znaczaca rolę odegrali też stronnicy Białej Cerkwi w izbie poselskiej, a zwłaszcza posłowie czernihowscy Kajetan Kurdwanowski i Kajetan Miączyński, poseł lubelski Wojciech Suchodolski oraz przedstawiciel ziemi chełmskiej Piotr Lubowiecki63.

58 Dyaryusz Seymu... 1782..., s. 133-393.

59 Tabele jawnych wotowań w senacie i wyniki głosowań znajdują się w: AGAD, APP nr 313, t. XI, s. 323-366; tabele jawnych głosowań w izbie poselskiej znajduja się w: AGAD, ZP nr 108, k. 29-88v. Por. też A. S t r o y n o w s ki , op. cit., s. 163-164; W. Fili p c z a k, Ekonomie litewskie..., s. 272.

60 Suplement wiadomości de die 24 octobris 1782, [w:] T. O s trow s ki, op. cit., s. 188; W. Fili p c z a k, Uwagi o funkcjonowaniu „wolnych” sejmów okresu Rady Nieustajacej (1778-1786), [w:] Parlamentaryzm w Polsce we współczesnej historiografii, red. J. Bardach i W. Sudnik, Warszawa 1995, s. 117. Por. też J. M ichalski, Sejm $w$ czasach panowania Stanisława Augusta, [w:] Historia sejmu polskiego, t. I, red. J. Michalski, Warszawa 1984, s. 380.

61 Tabele głosowań w izbie poselskiej, AGAD, ZP nr 108, k. 31v, 35v, 66v, 70v. Na temat kandydatury do laski marszałkowskiej proponowanej przez Stanisława Augusta, por. król do Michała Granowskiego, 13 II 1782, BCz, rkps 663, s. 235.

62 Dyaryusz Seymu... 1782..., s. 183-184; K. Ru d n i c k i, op. cit., s. 233.

63 Dyaryusz Seymu... 1782..., s. 169-172, 174-177, 219-223, 226-227; notatka, b.d., AGAD, ZP nr 126, k. 218; E. R o s tw o r ow s ki, Kurdwanowski Kaje- 
W efekcie oddziaływania wielu okoliczności sejm z roku 1782, jako jedyny „wolny” (nieskonfederowany) tego okresu nie uchwalił absolutorium („kwitu”) dla żadnego organu władzy wykonawczej oprócz Rady Nieustającej64. Bardzo ubogo przedstawiała się też jego działalność ustawodawcza. Przyjęto jedynie cztery konstytucje, które promowane były przez państwa zaborcze65. Symboliczne jest, iż projekt Zniesienie poboru od furmanów, który od dłuższego czasu był przedmiotem zabiegów dyplomacji austriackiej, został zgłoszony przez jednego $z$ przywódców Nowej Familii, posła wileńskiego Adama Kazimierza Czartoryskiego66. Wpływ obcych dyplomatów na obrady parlamentu to osobny problem, który nie mieści się w ramach mojego tematu. Warto zauważyć, że Stanisław August rozpowszechniał pogląd, iż brakiem rezultatów sejmu był zainteresowany dwór wiedeński, który posłużył się w tym celu opozycją. Regaliści twierdzili, że Austria nie chciała dopuścić do uchwalenia, zgłoszonego „od tronu”, projektu w sprawie poszukiwań soli i kruszców. Aby temu zapobiec, Wiedeń był gotów nawet zaproponować korzystniejszy kontrakt solny ${ }^{67}$. Osobnym problemem jest postawa O. Stackelberga, którego (według relacji regalistów) przeciwko królowi mieli podżegać wojewodowie Szymon Dzierzbicki i August Sułkowski, niezadowoleni $z$ wyników sejmowych elekcji68. Stanisław August jeszcze przed sejmem próbował doprowadzić do porozumienia z przywódcami Nowej Familii (S. Lubomirskim, A.K. Czartory-

tan, [w:] PSB, t. XVI, Wrocław 1971, s. 234; W. S zczygi els ki, Miaczyński Kajetan, [w:] PSB, t. XX, Wrocław 1975, s. 562; M. Podgó rzak, Suchodolski Wojciech, [w:] PSB, t. XLIV, Warszawa-Kraków 2008, s. 304.

64 Z. S z cząska, Odpowiedzialność rzadu w Polsce $w$ latach 1775-1792, "Czasopismo Prawno-Historyczne” 1975, t. XXVII, z. 1, s. 79; J. Mich alski, Sejm w czasach panowania..., s. 379.

65 Vol. leg., t. IX, Kraków 1889, s. 4-5; W. F i 1 i p c z a k, Sejmy Rzeczypospolitej..., s. 74.

66 Zniesienie poboru od furmanów (projekt $z$ podpisem A.K. Czartoryskiego), AGAD, ZP nr 108, k. 15; Dyaryusz Seymu... 1782..., s. 286-287, 289, 363; ekstrakty not Johanna Thuguta $z 3$ II 1782 oraz 2 VI 1782, AGAD, ZP nr 31, k. 168$169 \mathrm{v}, 171-172$.

67 „W Warszawie z 12 XI 1782” (pismo polityczne w formie listu), AGAD, ZP $\mathrm{nr} 126, \mathrm{k} .423 \mathrm{v}$. Plany poszukiwań soli król promował już w propozycjach od tronu w 1780 (Dyaryusz Seymu... 1780..., s. 33). Por. też E. Z i eliń s ka [rec.:], A. Stroynowski, Opozycja sejmowa $w$ dobie rzadów Rady Nieustajacej..., „Wiek Oświecenia. Miscellanea” 2007, s. 272.

68 „W Warszawie z 11 XI 1782” (pismo polityczne), AGAD, ZP nr 126, k. 422v423. Por. D. Dukwicz, M. Zwierzykowski, Sulkowski August, [w:] PSB, t. XLIV, Warszawa-Kraków 2006, s. 550. 
skim, I. Potockim i S.K. Potockim) ${ }^{69}$. W czasie sejmu król proponował kompromis liderom opozycji (S. Lubomirskiemu, A.K. Czartoryskiemu, F.K. Branickiemu). Miał on polegać na przyjęciu, w zamian za zamknięcie sprawy sołtykowskiej, przygotowanego przez pieczętarzy projektu w sprawie kurateli. Wiązało się to, m.in., z podnoszonymi przez opozycję zarzutami, że w skład komisji królewskiej badającej stan zdrowia K. Sołtyka wchodziły osoby, które nie miały posesji w województwie krakowskim ${ }^{70}$. W końcowej fazie sej$\mathrm{mu}$, za pośrednictwem A.K. Czartoryskiego, monarcha ponowił ofertę kompromisu. Stanisław August liczył, że opozycja po porażce w kolejnych głosowaniach, przyjmie jego warunki ${ }^{71}$.

Ciekawe światło na wydarzenia rozgrywajace się za kulisami parlamentarnymi rzuca posejmowa korespondencja Stanisława Augusta z E. Sapieżyna, której fragmenty opublikował (nie zawsze precyzyjnie) Bronisław Zaleski w Korespondencji krajowej Stanisława Augusta. Wymaga ona jednak pełniejszego i bardziej wszechstronnego omówienia. W dniu 26 listopada 1782 r. wojewodzicowa mścisławska skarżyła się królowi, że doznaje z jego strony „zgryzoty, prześladowania i odgróżek najsroższych"72. Podkreślała swoja niewinność i chęć wyjaśnienia przyczyn królewskiego gniewu. Poczatkowo nie chciała wierzyć w plotki na ten temat. $Z$ czasem jednak przekonała się, że niechęć monarchy jest prawdą. Podkreślała swoją bezinteresowność (co nie brzmiało zbyt szczerze) i przywiazanie do króla, któremu „służy lat 18”" nie odbierała tak obficie lask monarszych, jak o tym „powiadaja”. Jej szczególny niepokój wywołały zapowiedzi, że Stanisław August „będzie się mścił do ostatniego momentu życia swego"74. Powoływała się na usłyszane opinie, że jest to reakcja na głosy „posłów, ministrów i senatorów" w sprawie kapituły krakowskiej. Wyraziła,

69 Notatki z rozmów króla z S. K. Potockim (z 26 IX 1782), I. Potockim, S. Lubomirskim i A.K. Czartoryskim (wszystkie z 27 IX 1782), AGAD, ZP nr 126, k. 205-209.

70 Notatkę na temat spotkania króla z S. Lubomirskim, A.K. Czartoryskim i F.K. Branickim oraz różne wersje projektu można znaleźć w: AGAD, ZP nr 126, k. 15-20. Zarzuty dotyczace składu komisji królewskiej por. „Kopia listu pisanego z Krakowa...” i „Myśli ad agendum”, AGAD, APP nr 313, t. XI, s. 211, 239.

71 Notatka króla $z$ rozmowy $z$ A.K. Czartoryskim, 4 XI 1782, AGAD, ZP nr 126, k. 84-85v.

72 Elżbieta Sapieżyna do króla, 26 XI 1782, BCz, rkps 931, s. 105. Por. B. Z a 1 e s ki, op. cit., s. 14.

73 E. Sapieżyna do króla, 26 XI 1782, BCz, rkps 931, s. 105-108.

74 E. Sapieżyna do króla, 26 XI 1782, ibidem, s. 109-110. 
dość obłudnie, zdziwienie, że wystapienia w sprawie publicznej moga być odbierane jako przeciwne królowi. Pisała, iż Stanisław August „zawołanym do siebie ministrom powiedział, że sam to znasz, że kapituła źle zrobiła"75. E. Sapieżyna podkreślała, że król nie powinien „naganiać” wolnego głosu. Księżna wskazywała, że nie może ponosić odpowiedzialności za mowy sejmowe, podobnie jak K.N. Sapieha, który nie był w roku 1782 posłem (nie mógł nim zostać jako konsyliarz Rady) ${ }^{76}$. Wojewodzicowa mścisławska nie ukrywała, że $\mathrm{w}$ sprawie krakowskiej zgadzała się z poglądami opozycyjnych parlamentarzystów. Podkreślała jednak, iż nie miała możliwości wpływania na przebieg debaty. Wojewodzicowa pisała „od Sejmu [17]므, [17] $\underline{80}$ aż do tego ostatniego nasz dom jest bez przestanku dręczony"77. Były to nawiazania do wspomnianych spraw poselstwa z sejmiku słonimskiego (1776 r.) i marszałkostwa Rady Nieustajacej (1780 r.). Nie zabrakło także odwołań do królewskiej litości. E. Sapieżyna pisała „nic nie jest łatwiejszego, jak dokuczyć i upokorzyć kobitę dobrze myśląca"78.

Stanisław August odpowiedział na list księżnej wojewodzicowej 28 listopada 1782 r. Król zaznaczył, że nie zamierza odpisywać „na każdy punkt" jej listu. Musiałby bowiem przypominać szczegóły nieprzyjemne dla adresatki, a znane "całemu krajowi” i jej samej. Monarcha podkreślał, że do tej pory był „obrońca nie tylko interesów, ale postępków WKsMci”79. Jednak zachowanie księżnej na tym sejmie odebrało mu "sposób” dalszej obrony. Stanisław August uznał, że nie miała żadnych powodów, by zapominać o dawnych obowiązkach i zapewnieniach dozgonnej wdzięczności. Król pisał, „że się każdy zadziwiać musiał nad Damą, z rozumu i przymiotów dotychczas tak dobrze znana, a która nad wszelka przyzwoitość płci i sytuacji swojej, tak się Sejmem opiekowała, tak na nim częstowała w izbie poselskiej, jak czasem na sejmikach czynić się trafiało innym damom, kiedy której szło o męża, o syna, o najmilszego przyjaciela, a jednak nie bez nagany ilekroć na chórach ko-

75 E. Sapieżyna do króla, 26 XI 1782, ibidem, s. 110-111.

76 E. Sapieżyna do króla, 26 XI 1782, ibidem, s. 111; Ł. K ą d zi e la, op. cit., s. 53.

77 E. Sapieżyna do króla, 26 XI 1782, BCz, rkps 931, s. 111-112. Por. B. $Z$ a le s ki, op. cit., s. 14 .

78 E. Sapieżyna do króla, 26 XI 1782, BCz, rkps 931, s. 113.

79 Król do Elżbiety Sapieżyny, 28 XI 1782, ibidem, s. 115; B. Z a le s k i, op. cit., s. 15. 
ścielnych kornety widziano podczas sejmiku"80. K.N. Sapieha, nie będac posłem na sejm, nie musiał zajmować stanowiska, „a jednak największą żwawością dystyngował się przeciwko zdaniu i żądaniu memu”81. Król przypominał „proroctwa” tych, którzy ganili go za zbyt wcześnie okazywane mu łaski. Należy przypomnieć, że K.N. Sapieha otrzymał od monarchy urząd generała artylerii litewskiej, mając zaledwie 16 lat 82 . Stanisław August oceniał, że opozycja syna E. Sapieżyny pochodziła „z własnych darów moich”. Dalej pisał „Skutki byłyby na koniec zniszczeniem wszelkiej wagi i konsyderacji mojej w kraju, gdybym dalej dozwalał szerzyć się tym szkodliwym dla mnie staraniom i poniekad sam dodawał na to sposobów"83. Podkreślał, że oskarżanie osób ,jedno ze mna rozumiejacych" o łamanie sprawiedliwości, prawa i wolności godziło w samego monarchę. Wskazywał, że nie zamierza "tym się powierzać", którzy przeciwko niemu występują. Wyjaśniał, że nie jest to zemsta, lecz „własna obrona”. Stanisław August kończył list prośba „ażebyś W. Ks. Mość nie raczyła w dalsze piśmienne dysceptacje o tych materiach ze mną wchodzić, bo więcej na nie nie odpowiem, ani zdania odmienić nie mogę"84.

E. Sapieżyna nie wzięła sobie jednak do serca królewskiego apelu. W Warszawie 7 grudnia 1782 r. napisany został kolejny, bardzo obszerny, list. Księżna powoływała się na prawo oskarżonego do obrony. Sugerowała, że w otoczeniu monarchy nie ma osób życzliwych jej domowi, liczni są natomiast oskarżyciele ${ }^{85}$. Podkreślała, że nigdy ich zamiarem nie było dokuczać komuś lub szkodzić królowi. Wojewodzicowa stwierdzała zarazem, że nie interesuje ja akceptacja innych osób, a jedynie monarchy. Za tym twierdzeniem szła sugestia, iż Stanisław August nadmiernie ulega ocenom („zaświadczeniom”) swojego otoczenia86. E. Sapieżyna odrzucała królewski zarzut, że „opiekowała się” ostatnim sejmem. Negowała, że była osobiście zainteresowana sprawą krakowska.

80 Król do E. Sapieżyny, 28 XI 1782, BCz, rkps 931, s. 116; B. Z a le s k i, op. cit., s. 15 .

${ }^{81}$ Król do E. Sapieżyny, 28 XI 1782, BCz, rkps 931, s. 116-117; B. Z a le s ki, op. cit., s. 15 .

82 Ł. K a d $z$ i e 1 a, op. cit., s. 52.

83 Król do E. Sapieżyny, 28 XI 1782, BCz, rkps 931, s. 117; B. Z a le s k i, op. cit., s. 15.

${ }^{84}$ Król do E. Sapieżyny, 28 XI 1782, BCz, rkps 931, s. 118.

85 E. Sapieżyna do króla, 7 XII 1782, ibidem, s. 119.

86 E. Sapieżyna do króla, 7 XII 1782, ibidem, s. 120-122. 
Zaprzeczała, iż próbowała nakłaniać do aktywności inne osoby. Kwestionowała też oskarżenia pod adresem K.N. Sapiehy, o którym mówiono, „że po posłach jeździł w nocy, a on i w dzień u żadnego nie był. Żona by go do kościoła przez siebie nie puściła" 87 . Pominę tu komentarz do opinii E. Sapieżyny o swojej synowej, wartej jednak odnotowania w kontekście słynnego później w całej Rzeczypospolitej rozwodu88. Ciekawie brzmia wyjaśnienia wojewodzicowej mścisławskiej na temat, wspominanych w liście królewskim, poczęstunków w izbie poselskiej. Oceniała powyższą informacje jako fałszywa. Przyznawała jednak, że jeden raz, kiedy w ciagu dnia odbyły się dwie sesje, posłowie opozycyjni prosili F.K. Branickiego, ażeby przysłał im jedzenie „do przedpokoju księcia Biskupa Płockiego", gdzie w czasie sejmu często spożywali posiłki posłowie i arbitrowie. Zgodnie $z$ tym życzeniem, księżna wojewodzicowa po powrocie do domu, wysłała opozycyjnym parlamentarzystom obiad. Wyjaśniała, że choć oceniała sprawę kapituły krakowskiej tak jak oni, nie tylko ich nie „animowała”, lecz nawet temperowała nastroje. Księżna przypominała również, że posłowie regalistyczni zaproszeni zostali na posiłek przez kasztelana podlaskiego Tomasza Aleksandrowicza, marszałka dworu królewskiego ${ }^{89}$.

Opisane przez E. Sapieżynę wydarzenia miały zapewne miejsce 2 listopada 1782 r., kiedy odbyły się sesje poranna i popołudniowa (XXIX i XXX), na których, m.in., przyjęto wspomnianą konstytucję Zniesienie poboru od furmanów, a także rozstrzygano trzeci i czwarty punkt projektu $O$ rezolucjach Rady S.K. Potockiego ${ }^{90}$. Dzień wcześniej sporządzono notatkę, w której Stanisław August rozważał możliwości efektywnego wykorzystania ostatnich dni sejmu („zakwitowanie" pozostałych magistratur, uchwalenie projektu Dekreta executionis, propozycji w interesie Radziwiłłów oraz nadanie indygenatów) ${ }^{91}$. Monarcha chciał, za pośrednictwem wojewody ma-

87 E. Sapieżyna do króla, 7 XII 1782, ibidem, s. 123.

$88 \mathrm{~K}$. K oź mi a n, Pamiętniki, wstęp i komentarz J. Willaume, t. I, Wrocław 1972, s. 117-124; Ł. Ka d z i e la, op. cit., s. 54.

89 E. Sapieżyna do króla, 7 XII 1782, BCz, rkps 931, s. 123-124. Na temat roli kasztelana T. Aleksandrowicza w poczatkach obrad Sejmu Wielkiego por. E. Ros tw o row ski, Ostatni król Rzeczypospolitej. Geneza i upadek Konstytucji 3 maja, Warszawa 1966, s. 158-159.

90 Dyaryusz Seymu... 1782..., s. 362-371, 376-391.

91 Notatka $z 1$ XI 1782, AGAD, ZP nr 126, k. 300-300v. Wymienione przez monarchę sprawy doczekały się realizacji dopiero na sejmie grodzieńskim w 1784 . Por. Vol. leg., t. IX, s. 11-19, 24. 
zowieckiego Andrzeja Mokronowskiego, starać się o zgodę O. Stackelberga na przedłużenie lub skonfederowanie sejmu. Przeszkoda w dalszych obradach mógł być jednak wniosek Moszczeńskich, który dotyczył uchylenia decyzji Rady w sprawie potajemnych małżeństw ${ }^{92}$. Projekt Warunek dla Korony $i$ W. Ks. Litewskiego, przewidujacy unieważnienie rezolucji z 22 marca 1782 r., został przedstawiony w izbie poselskiej 28 października 1782 r. (na XXV sesji) ${ }^{93}$. Stanisław August chciał, za pośrednictwem protektora Moszczeńskich - wojewody ruskiego S. Szczęsnego Potockiego (wówczas regalisty), powstrzymać dyskusję w tej sprawie ${ }^{94}$. Monarcha liczył, że dzięki A.K. Czartoryskiemu uda się skłonić opozycję do zaniechania debaty nad kolejnymi punktami projektu S.K. Potockiego. Generał ziem podolskich mógłby w ten sposób zasłużyć się Austrii pomoca w uchwaleniu popieranej przez Wiedeń propozycji. Król obawiał się, że dyskusja o uchyleniu rezolucji w sprawie małżeństw (która monarcha uważał za słuszna) może zabrać resztki czasu sejmowego, co obciąży regalistów odpowiedzialnościa za niepowodzenie obrad ${ }^{95}$. Należy w tym miejscu przypomnieć, że wspomniany projekt Moszczeńskich kwestionował rezolucję, która chroniła interesy Sapiehów. Ostatecznie, jak wiadomo, do kompromisu nie doszło. Rodzi się jednak pytanie, czy zaangażowanie E. Sapieżyny w działania opozycji nie miało zwiąku $z$ obawami, że w wypadku skrócenia debat nad projektem S.K. Potockiego regaliści moga zakwestionować wspomniana rezolucję Rady.

Relacja E. Sapieżyny wskazuje, że podziały występujące w czasie goracych debat sejmowych przenoszone były na poziom życia codziennego. Ujawnia zarazem duża determinację obu stron konfliktu, jeśli idzie o zachowanie jedności swojego stronnictwa. W dalszej części listu z 7 grudnia 1782 r. E. Sapieżyna podkreślała, że jej stronnicy nie występowali przeciwko Stanisławowi Augustowi. Wojewodzicowa mścisławska twierdziła, że wkrótce po ubezwłasnowolnieniu biskupa krakowskiego król miał ganić te działania96. Księżna powoływała się na, przekazaną przez F.K. Branickiego, opinię, jakoby monarcha negatywnie ocenił wobec ministrów po-

92 Notatka $z 1$ XI 1782, AGAD, ZP nr 126, k. 300-301.

93 Dyaryusz Seymu... 1782..., s. 293.

94 Notatka z 1 XI 1782, AGAD, ZP nr 126, k. 300v-301; E. R o s tw o r o w s k i, Moszczeński Adam, [w:] PSB, t. XXII, Wrocław 1977, s. 87.

95 Notatka z 1 XI 1782, AGAD, ZP nr 126, k. 300v-301v.

96 E. Sapieżyna do króla, 7 XII 1782, BCz, rkps 931, s. 125. 
stępowanie kapituły i mówił, że można ją krytykować bez narażania się królowi. Hetman wielki koronny miał przekazać tę informację posłom ${ }^{97}$. Wiadomość o działaniach F.K. Branickiego wyjaśnia, przynajmniej w części, zamieszanie $\mathrm{w}$ szeregach regalistów, do jakiego doszło w poczatkowej fazie debaty. Było to widoczne zwłaszcza wśród posłów litewskich (może dlatego biskup Józef Kossakowski wyśmiewał się $z$ „małego kredytu” podkanclerzego Joachima Chreptowicza) ${ }^{98}$. Zwraca uwage, że największe poparcie $\mathrm{w}$ izbie poselskiej opozycja uzyskała w głosowaniu nad pierwszym punktem projektu S.K. Potockiego99. W dalszej części listu E. Sapieżyna ponownie zarzuciła królowi nadmierne uleganie podszeptom otoczenia. Wskazywała, że obrona kapituły nie przysporzyła monarsze popularności w narodzie100. Na uwage zasługuje też odpowiedź księżnej na ironiczne uwagi króla dotyczące politycznej aktywności kobiet (Stanisław August podejmował ten wątek także w korespondencji z Aleksandra Ogińską ${ }^{101}$ ). „Bardzo mądra i wymowna dama”, jak ja opisywał Marcin Matuszewicz ${ }^{102}$, tak napisała do monarchy: „Kobity co ich Sejm bawi i interesuje lubo niesłusznie WKMć $z$ tej płci uragasz się, jak jego listu wyrazy oznaczaja, lubo tej płci nie tylko WKMć winien początkowe swoje szczęście, ale i w przeciagu panowania swego doznawałeś od wielu istotnych usług"103. Przypomnienie okoliczności towarzyszących elekcji nie mogło być, jak sądzę, dla Stanisława Augusta przyjemne.

W końcowej części listu z 7 grudnia 1782 r. E. Sapieżyna podniosła problem „zazdrości, prześladowania i upokorzenia”, jakich na sejmie miał doznawać jej syn. Nawiąując do projektu Moszczeńskich, księżna pisała o zamiarze sięgnięcia po jego fortunę. Tym tłumaczyła, że wbrew własnej chęci, jak twierdziła, zmuszony był „udać się do cudzej protekcji”104. Prawdopodobnie księżnej chodziło o interwencję w interesie K.N. Sapiehy ze strony Johanna Thuguta. Wiadomo, że treść biletu posła austriackiego przekazał

97 E. Sapieżyna do króla, 7 XII 1782, ibidem, s. 126-127.

98 W. Fili p c z a k, Ekonomie litewskie..., s. 273. Por. J. Kos s a k ow ski, Pamiętniki biskupa inflanckiego..., wyd. A. Darowski, Warszawa 1891, s. 139.

99 A. S tro y n ow s ki, op. cit., s. 164 (przyp. 2).

100 E. Sapieżyna do króla, 7 XII 1782, BCz, rkps 931, s. 127-129.

101 Król do Aleksandry Ogińskiej, 11 VIII 1783, BCz, rkps 678, s. 250-251.

102 M. M a tu s z ew i c z, op. cit., t. II, s. 167.

103 E. Sapieżyna do króla, 7 XII 1782, BCz, rkps 931, s. 129; B. Z a le sk i, op. cit., s. 16.

104 E. Sapieżyna do króla, 7 XII 1782, BCz, rkps 931, s. 131. 
królowi A.K. Czartoryski, za pośrednictwem A. Cieciszowskiego. Stanisław August zapewniał 4 listopada 1782 r. starostę generalnego ziem podolskich, że wbrew opinii J. Thuguta, nie nastawiał regalistycznych posłów przeciwko generałowi artylerii litewskiej105. Król sugerował, że niechęć wynikała $z$ konfliktu interesów majątkowych Sapiehy i niektórych posłów. Dodawał jednak, że mogła się do niej przyczynić nadmierna „żwawość" wystąpień posłów opozycyjnych, które „rozgrzały” regalistów. W tej sytuacji, gdy i tak nie było szansy na konstruktywne działania sejmu, król nie miał możliwości (a zapewne i ochoty) ich powstrzymywać106. Takie nastawienie regalistów znalazło wyraz na sesji z 4 listopada 1782 r. (ostatniej w izbach rozłączonych), kiedy to A. Moszczeński próbował doprowadzić do unieważnienia rezolucji Rady w sprawie potajemnych małżeństw'107.

Stanisław August, zgodnie z zapowiedzia, nie odpisał na list E. Sapieżyny. Stanowisko monarchy w tej sprawie nie jest jednak tajemnica. Znamy je $z$ projektowanego listu do księżnej, który, jak wynika $z$ notatki na marginesie, nie został wysłany. O stanowisku króla adresatka została poinformowana ustnie. Stanisław August przede wszystkim stanowczo zaprzeczył, jakoby w Gabinecie wobec F.K. Branickiego i innych ministrów powiedział, „że kapituła źle zrobiła, że chcę, aby o tym gadali i ukarali, byle nie zarzynali"108. Negował również informację, jakoby w czasie pobytu hetmana wielkiego w Petersburgu, miał w podobny sposób pisać do Augustyna Debolego. Król odniósł się także do poczynań K.N. Sapiehy w ostatnich dniach sejmu, a dokładniej „zaraz po podpisaniu rozgraniczenia ratyfikacji"109. Wiadomość zawarta w liście nie jest precyzyjna. W zasadzie mogła się odnosić do sesji z 24 i 26 października 1782 r., kiedy sejm przyjął projekty trzech ustaw zwiazanych $z$ ustaleniem przebiegu granic. Niewattpliwie chodziło jednak o pierwsza (uchwalona 24 października), która dotyczyła ratyfikacji delimitacji Rzeczypospolitej i Rosji, a dokładniej polskiej Ukrainy z Nowa Ro-

105 Notatka $z$ rozmowy króla $z$ A.K. Czartoryskim z 4 XI 1782, AGAD, ZP nr 126, k. 84. Por. „W Warszawie z 12 XI 1782” (pismo polityczne), ibidem, k. 423v424.

106 Notatka $z$ rozmowy króla $z$ A.K. Czartoryskim z 4 XI 1782, AGAD, ibidem, k. 84-84v.

107 Dyaryusz Seymu... 1782..., s. 394-395.

108 Król do E. Sapieżyny, bez daty, zapewne z 7 XII 1782 (list nie został wysłany), BCz, rkps 931, s. 159.

109 Król do E. Sapieżyny, bez daty, ibidem, s. 159-160. 
sją. Dwie kolejne konstytucje (przyjęte 26 października) związane były $z$ rozgraniczeniem dóbr prywatnych na pograniczu państwa pruskiego $z$ Wielkopolska ${ }^{110}$. K.N. Sapieha miał powiedzieć 24 października: „Cieszcie się Wać Państwo $z$ tej jednej konstytucji, bo też upewniam, że insza żadna nie stanie"111. Choć, jak wiadomo, ta zapowiedź nie została w pełni zrealizowana, król oskarżył generała artylerii o zamiar psucia sejmu na wzór czasów Augusta III. Stanisław August stwierdzał, że w ten sposób nie pozwolono mu przeprowadzić korzystnych dla kraju inicjatyw. Powoływał się na swój projekt w sprawie funduszu na poszukiwanie soli i kruszców, który można było ustanowić bez nakładania nowego podatku. Realizacja królewskiej inicjatywy miała zwiększyć dochody państwa, a tym samym umożliwić aukcję wojska, o czym tak chętnie wspominała opozycja. Monarcha przypomniał też projekt Dekreta executionis, który spotkał się $\mathrm{z}$ pozytywna ocena $\mathrm{w}$ czasie dwóch kolejnych sejmów ${ }^{112}$. Był on wnoszony w propozycjach od tronu w roku 1780 i 1782; doczekał się zaś uchwalenia dopiero w roku 1784, na sejmie grodzieńskim ${ }^{113}$.

Do wymiany opinii na temat losów sejmu z 1782 r. król i E. Sapieżyna wrócili w marcu $1783 \mathrm{w}$ zmienionej sytuacji politycznej. Było to zwiazane ze staraniami K.N. Sapiehy o kupno starostwa brzeskiego od Ignacego Morykoniego. Matka generała artylerii litewskiej korzystała $\mathrm{w}$ tej sprawie $\mathrm{z}$ pośrednictwa O. Stackelberga $^{114}$. Księżna wojewodzicowa w dwóch listach do króla (z 14 i 27 marca) odnosiła się do ostatnich sejmów ${ }^{115}$. Król zaprezentował swoje stanowisko w liście z 19 marca 1783 r. oraz w czasie, odbytej 11 kwietnia 1783 r., rozmowy z K.N. Sapiehą ${ }^{116}$. Nowa wymiana

110 Notatka z rozmowy króla z K.N. Sapieha, 11 IV 1783, ibidem, s. 181-182; Dyaryusz Seymu... 1782..., s. 255, 279; Vol. leg., t. IX, s. 4-5.

111 Król do E. Sapieżyny, bez daty, BCz, rkps 931, s. 160.

112 Król do E. Sapieżyny, bez daty, ibidem, s. 161. Por. B. Z a le s k i, op. cit., s. $17-18$.

113 Vol. leg., t. IX, s. 15-19. Dekreta executionis (całość projektu została w wydawnictwie potraktowana jako 3 osobne konstytucje).

114 Elżbieta Sapieżyna do króla, 14 III 1783, kopie biletów Ottona Stackelberga do E. Sapieżyny oraz bilet E. Sapieżyny do króla, BCz, rkps 931, s. 143148; B. Zaleski, op. cit., s. 16-17. Por. też W. Fili pczak, Ekonomie litewskie..., s. 261-262.

115 E. Sapieżyna do króla, 14 i 27 III 1783, BCz, rkps 931, s. 150-151, 164 166, 170-172.

116 Król do E. Sapieżyny, 19 III 1783 oraz notatka $z$ rozmowy króla $z$ K.N. Sapieha, 11 IV 1783, ibidem, s. 155-156, 181-187. 
zdań nie wniosła wiele do interesujaccego mnie problemu. Obie strony sporu pozostały przy swojej ocenie wydarzeń. Odnotować należy jednak mocne zaakcentowanie przez księżną (14 marca 1783 r.) upokorzenia, którego jej syn doznał na sejmie $z$ roku 1780 od rodziny królewskiej ${ }^{117}$ (sprawa marszałkostwa Rady). W drugim liście (z 27 marca) wojewodzicowa mścisławska podkreślała, że sejmowe ataki na kapitułę, nawet jeśli były zbyt „żwawe”, nie były szkodliwe dla króla. Sugerowała również, iż mogłaby się przyczynić do tego, że na kolejnym sejmie sprawa nie stanie się przedmiotem debaty, czego obawiał się monarcha ${ }^{118}$. E. Sapieżyna przyznawała, iż jej syn w czasie sejmu mógł wyrażać swój pogląd w sprawie kapituły. Przysięgała jednak, „że nikt mu nie dowiedzie, aby miał co mówić takiego, za co by się mógł wstydzić"119. Stanisław August $\mathrm{w}$ zasadzie jedynie powtórzył prezentowane już zarzuty. Pojawiały się też nowe pretensje związane $z$ relacją sejmowa Stanisława Niemcewicza na sejmiku gromnicznym w Brześciu Litewskim ${ }^{120}$. Do wątków poruszanych przez księżna król nawiąał w czasie kwietniowego spotkania $z$ K.N. Sapieha, któremu w Warszawie towarzyszył strażnik koronny Józef Mierzejewski (blisko zwiazany $z$ E. Sapieżyna). Monarcha ponowił w rozmowie oskarżenia skierowane wcześniej do matki generała artylerii. Król odwołał się do słów (wcześniej cytowanych), które miał K.N. Sapieha powiedzieć po ustawie w sprawie ratyfikacji granicznej. Generał artylerii litewskiej zasłaniał się wiadomościami F.K. Branickiego o rzekomo krytycznej opinii monarchy na temat postępowania kapituły. Po sejmowej mowie króla, jak twierdził, zaprzestał jednak dalszych działań121. Chodziło zapewne o wystapienie Stanisława Augusta na sesji 23 października 1782 r., przed rozłączeniem się izb122. Król zanegował tę argumentację wskazując, że wspomniana wypowiedź Sapiehy miała miejsce już po rozdzieleniu się stanów sejmowych ${ }^{123}$.

117 E. Sapieżyna do króla,14 III 1783, ibidem, s. 150.

118 E. Sapieżyna do króla, 27 III 1783, ibidem, s. 164-165, 170-171; B. Z a 1 e ski, op. cit., s. 18. Na temat niepokoju króla o wznowienie sprawy sołtykowskiej na kolejnym sejmie por. król do Józefa Stempkowskiego, 10 VII 1783, BCz, rkps 688, s. 517-518.

119 E. Sapieżyna do króla, 27 III 1783, BCz, rkps 931, s. 171.

120 Król do E. Sapieżyny, 19 III 1783, ibidem, s. 156.

121 Notatka $z$ rozmowy króla $z$ K.N. Sapiehy, 11 IV 1783, ibidem, s. 181-182.

122 Dyaryusz Seymu... 1782..., s. 236-240.

123 Notatka z rozmowy króla z K.N. Sapiehy, 11 IV 1783, BCz, rkps 931, s. 182 . 
Istotnym elementem rozmowy był wątek ataków opozycji na brata królewskiego (jako beneficjanta ubezwłasnowolnienia biskupa krakowskiego) oraz synowca monarchy (jako marszałka Rady Nieustającej w latach 1780-1782). Stanisław August podchwycił, zasugerowany wypowiedzia generała artylerii, motyw rewanżu za wydarzenia sejmu 1780 r. Domagał się również obietnicy, że stronnicy Białej Cerkwi nie będą próbowali wracać do sprawy krakowskiej w przyszłości. Monarcha oczekiwał także deklaracji współdziałania $z$ regalistami na forum parlamentarnym ${ }^{124}$.

Pozostaje pytanie, czy rzeczywiście opozycyjne działania stronnictwa białocerkiewskiego na sejmie roku 1782 były rewanżem za porażke K.N. Sapiehy w staraniach o marszałkostwo Rady Nieustającej. Król zdawał się przyjmować takie wyjaśnienie. Należy jednak pamiętać, że sytuacja monarchy nie była komfortowa. Nie mógł odmówić generałowi artylerii zgody na zakup starostwa brzeskiego, gdyż ten cieszył się protekcją G. Potiomkina ${ }^{125}$. Nie można wykluczyć, że było to przysłowiowe robienie dobrej miny do złej gry. Inne motywy działań opozycji hetmańskiej sugerują wypowiedzi F.K. Branickiego z lata 1783 r., które relacjonował królowi Szczęsny Potocki. Hetman wielki koronny twierdził wprawdzie, że potrafi oddać szykany dworskie, ale chodziło raczej o jego osobę, a nie o K.N. Sapiehę. F.K. Branicki mówił wojewodzie ruskiemu, że O. Stackelberg, w imieniu swojego dworu oświadczył, iż Katarzyna II chce, by „przyjaciele rosyjscy” łączyli się z „partia galicyjska”. Ta zaś „autoryzowana" była do obrony biskupa K. Sołtyka ${ }^{126}$.

Wymiana poglądów między Stanisławem Augustem a E. Sapieżyna i K.N. Sapiehą nie zakończyła sporu o losy sejmu $z$ roku 1782. Ważną rolę odgrywały również relacje poselskie składane na sejmikach. Zarówno dwór (tym razem regaliści wyjątkowo poważnie potraktowali tę sprawę), jak i opozycja (największy rozgłos zyskała relacja Adama Rzewuskiego) starały się przedstawić swoja

124 Notatka z rozmowy króla z K.N. Sapiehy z 11 IV 1783, ibidem, s. 184-185;

B. Z a le sk i, op. cit., s. 19.

125 W. Fili p c z a k, Ekonomie litewskie..., s. 261-262.

126 S. Szczęsny Potocki do króla, 6 VIII 1783, BCz, rkps 683, s. 448-449. Określenie „partia galicyjska” lub „stronnictwo austriackie” dotyczy Nowej Familii. Por. E. Ro s tw or ow s ki, Sprawa aukcji wojska..., s. 118-119; J. M i c h a 1 s ki, Do dziejów stronnictwa austriackiego i polskiej polityki Austrii po I rozbiorze, [w:] $Z$ dziejów wojny i polityki. Ksiegga pamiatkowa ku uczczeniu prof. dra Janusza Wolińskiego, Warszawa 1964, s. 139-145. 
wersję wydarzeń ${ }^{127}$. Zagadnienie to wykracza jednak poza ramy opisywanego tematu.

127 Król do Ludwika Wilgi, bez daty [1783], BCz, rkps 694, s. 234-235; Kopia relacji z czynności sejmowych... Adama Rzewuskiego... z 5 II 1783, AGAD, APP nr 313, t. XI, s. 281-289; W. Fili p c z a k, Stronnictwo regalistyczne..., s. 97. 